thyroidectomy on this reaction. Therefore, lack of thermothyrine A must be assumed as an explanation.

The fact that in later experiments similar results were obtained in animals treated with methylthiouracil raised the question whether methylthiouracil not only inhibits the formation of thy roxine but also the production of thermothyrine.

Dogs and rabbits were treated daily with $0 \cdot 10 \mathrm{gm}$. per kgm. methylthiouracil for four weeks, and were then subjected for five hours to a temperature of $34-35^{\circ} \mathrm{C}$., which raised their body temperature by $0.5-1 \cdot 5^{\circ} \mathrm{C} .2 .5$ c.c. of serum obtained at the end of the 5-hour period failed to reduce oxygen consumption of normal rats, while sera of untreated dogs and rabbits produced after similar exposure to high temperature a fall of oxygen consumption by 14-48 per cent. It is therefore evident that methylthiouracil inhibits the formation of both thyroxine and thermothyrine A.

The fact that thermothyrine A contains no iodine ${ }^{3}$ proves conclusively that the action of thiouracil compounds cannot be exclusively an inhibition of iodinization.

Institute of Pharmacology and

B. Berde

Experimental Pathology,

University of Pécs. Feb. 28.

"Mansfeld, G., "Die Hormone der Schilddrüse und ihre Wirkungen" (B. Schwabe and Co., Basel, 1943).

${ }^{2}$ Berde, B., Experientia, 2, 498 (1946).

${ }^{3}$ Mansfeld, A., Nature, 157, 491 (1946); and Schweiz. Med. Wsehr. (1946).

\section{A'Rapid Supra-vital Staining Method for Assessing the Viability of Human Spermatozoa}

We have developed a 4-minute technique for the supra-vital staining of spermatozoa which facilitates the estimation of viability and at the same time is suitable for the examination and counting of abnormal forms.

The method is based on the principle of Emmens ${ }^{1}$ for rabbit spermatozoa which, however, is unsuitable for human material.

Method : Supra-vital stain, 50 c.c. distilled water ; $1 \mathrm{gm}$. Revector Soluble Blue 706 ; $1.5 \mathrm{gm}$. glucose; $0.1 \mathrm{gm}$. sodium chloride; $0.3 \mathrm{gm}$. disodium hydrogen phosphate, hydrated; $0.005 \mathrm{gm}$. potassium dihydrogen phosphate, anhydrous. (This solution must be made up freshly, or alternatively it may be stored in $1 \mathrm{ml}$. ampoules and autoclaved.)

Counterstain: 1 per cent neutral red in distilled water.

Fixative: Half-volume saturated solution of mercuric chloride in distilled water; half-volume absolute alcohol; followed by 90 per cent alcohol containing a few drops of iodine in potassium iodide to give straw-coloured solution.

Four or five drops of seminal fluid are placed on a clean slide or in a small tube, and one drop of the supra-vital stain is added and well mixed. The mixture is left for 2-3 min. and one drop is withdrawn and a thin smear is made on a clean dry slide. The smear is allowed to dry in air, and is then fixed in the above fixative for 15-20 sec. ; the slide is then dipped into alcoholic iodine, and into 90 per cent alcohol, and allowed to dry. The counter-staining is effected by putting the slide into neutral red for $15-30$ sec., rinsing in water and differentiating with care in 90 per cent alcohol. The smear may then be dried and examined directly under oil immersion, or it may be passed through absolute alcohol and xylol and mounted in Canada balsam.

The nuclei of the spermatozoa which were dead when the seminal fluid was mixed with the stain are blue or purple; those that were alive are clear red, and a few non-nucleated forms remain unstained.

The stain does not kill living spermatozoa, since the motility of spermatozoa mixed with the soluble blueBaker's fluid solution is unaffected. We have found motile spermatozoa in the stain after a period of 36 hours. The decrease in motility of sperm in the stain solution is of the same order as that of sperm in its own seminal fluid.

\section{A. C. Crooke}

Anita M. Mandi

Endocrine Unit, London Hospital,

London, E.I. April 3.

${ }^{1} J$. Physiol.. in the press.

\section{Two Symbiotes of Psylla mali}

As a representative of Psyllid I selected Psylla mali, which, feeding on the apple tree, was easily available for investigation, and also for confirmatory work by other investigators. Profft ${ }^{1}$ has published the best account that has appeared on symbiosis in this group of insects. On p. 312, in Fig. 19, he illustrates a section of the bacteriotome, called by him, in conformity with others, a mycetome. Unfortunately, the magnification of the section is only 165 , which is exceptionally low for any cytological study. Further, he does not give any illustration of the symbiotes as seen in a smear of the tumour. In his illustration the majority of the tumour cells contain curved dark-staining objects. When I studied them in smears, stained with Giemsa, they appeared to be thick comma-shaped bacteria.

Profft's illustration, Fig. 19, also shows some tissue cells faintly stained, with contents very indistinct. These tumour cells contain very delicate and short bacteria which are best seen in smears stained with Giemsa.

A medium with apple juice was used for cultivating the symbiotic bacteria. The thick comma type of bacterium produced a bright green pigment like the colour of the insect. Morphologically, the tissue smear and that from the bacterial growth were identical. I noticed a cherry tree accidentally infected with Psylla mali; the insect which is usually green was now brownish-red. I made another medium with cherry extract. The medium was faintly coloured dirty pink. On plating, the comma. shaped symbiote of $P$. mali produced a bright cherry colour, like the colour of the insect feeding on the cherry tree. The share of the bacterium in producing a pigment derived from the food was thus evident.

The minor symbiote, the delicate bacterium, did not produce any pigment, and its role in the economy of the insect was not discovered.

This work was done some years ago, at Berlin, in the laboratory of Prof. F. F. Nord, now at Fordham University, New York. It is a pleasant duty to acknowledge his interest again here.

Research Institute,

S. Mahdirhassan

Osmania University,

Hyderabad.

March 5.

1Z. Morph. u. Okol., 32, 312 (1937). 